\title{
Ketangguhan Ekonomi Terhadap Bencana Kebakaran di Kota Pontianak
}

\author{
Aryasa Bijak Utama ${ }^{a}$ \\ a Program Studi Desain Kawasan Binaan, Jurusan Arsitektur, Politeknik Negeri Pontianak, Indonesia \\ E-mail Korespondensi: aryasabijakutama@gmail.com
}

\begin{abstract}
Abstrak: Kebakaran permukiman yang terjadi di Kota Pontianak jumlahnya lebih tinggi bila dibandingkan dengan Kota Singkawang, Kabupaten Pontianak, dan Kabupaten Mempawah (BPBD, 2015). Permasalahan ini diperburuk dengan adanya daya tarik Kota Pontianak untuk aktivitas bermukim dengan intensitas yang tinggi. Kepadatan Kota Pontianak tersebut dapat menimbulkan kerawanan bencana kebakaran di wilayah permukiman yang merata di setiap kecamatan. Penelitian ini bertujuan menemukenali tingkat ketangguhan ekonomi terhadap bencana kebakaran. Kaitannya terhadap kemampuan masyarakat dari sisi ekonomi terhadap investasi untuk membangun kembali rumah pasca bencana kebakaran. Metode penelitian ini menggunakan metode campuran (mixed methods) yaitu menggabungkan teknik analisis spasial dan analisis kualitatif. Variabel penelitian ini yaitu tingkat kemiskinan dan mata pencaharian. Hasil penelitian ini menunjukkan bahwa rumah tangga miskin terdapat 2 kecamatan yang menduduki skor 1 atau tingkat ketangguhan sangat tinggi yaitu pada kecamatan Pontianak Selatan dan Kecamatan Pontianak Tenggara. Untuk skor 2 atau tingkat ketangguhan yang tinggi juga diduduki oleh 2 kecamatan yaitu kecamatan Pontianak Kota dan kecamatan Pontianak Barat. Sedangkan skor 4 dan 5 masing masing hanya diduduki oleh satu kecamatan. Kawasan tangguh kebakaran dari sisi ekonomi cukup banyak di Kota Pontianak, yaitu terdapat 4 kecamatan dari 6 kecamatan yang ada di Kota Pontianak.
\end{abstract}

Kata Kunci: ketangguhan, ekonomi, bencana, kebakaran

How to cite (APA 6th Style):

Utama, Aryasa Bijak. (2020). Ketangguhan Ekonomi Terhadap Bencana Kebakaran di Kota Pontianak, 1(1), 12-19. doi: 10.26418/uniplan.v1i1.43035

\section{PENDAHULUAN}

Kebakaran adalah salah satu bahaya yang dapat mengancam wilayah perkotaan yang memiliki permukiman padat. Kawasan permukiman padat adalah ruang di kawasan perkotaan yang paling rentan terhadap ancaman bahaya kebakaran (Green dalam Sagala, 2014). Kepadatan penduduk yang terpusat di Kota Pontianak menyebabkan aktivitas di kawasan ini menjadi tinggi apabila dibandingkan dengan kota-kota lain yang ada di Kalimantan Barat. Semakin padatnya Kota Pontianak ini yang menyebabkan kawasan tersebut menjadi rentan untuk terjadi bencana kebakaran.

Kebakaran pada di kawasan permukiman tidak dapat dipungkiri memberikan kerugian bagi manusia baik itu kerugian materi maupun korban jiwa yang tidak sedikit. Menurut Suprapto dalam Mantra (2005) penyebab kebakaran utama di wilayah permukiman adalah hubungan arus pendek listrik 39,4\%, kompor minyak tanah 20\%, dan lampu tempel 9\%. Tidak jarang kebakaran juga disebabkan oleh hal sepele seperti putung rokok. Kebakaran terbanyak terjadi pada bangunan rumah tinggal $65,8 \%$ kemudian disusul bangunan pusat perbelanjaan dan pertokoan 9,3\%, selanjutnya bangunan industri (7,2\%), dan pertokoan (6,5\%).

Tabel 1. Kejadian Kebakaran Permukiman di Kalimantan Barat tahun 2010-2015 (BPBD Prov Kalbar, 2015)

\begin{tabular}{|c|c|c|c|c|c|c|}
\hline & \multicolumn{7}{|c|}{ Tahun } \\
\cline { 2 - 7 } Kecamatan & 2010 & 2011 & 2012 & 2013 & 2014 & 2015 \\
\hline Kota Pontianak & 47 & 52 & 46 & 48 & 51 & 55 \\
\hline Kota Singkawang & - & - & - & - & 26 & 5 \\
\hline Kabupaten Pontianak & - & 11 & 1 & - & & - \\
\hline Kabupaten/Kota Mempawah & - & - & - & - & 19 & 9 \\
\hline
\end{tabular}


Dari tabel 1 dapat dilihat kejadian kebakaran permukiman yang ada di Kota Pontianak apabila dibandingkan dengan kabupaten/kota lainnya jumlahnya sangat tinggi atau paling mendominasi. Tingkat kerentanan terhadap bencana kebakaran serta populasi penduduk yang terus meningkat di Kota Pontianak. Dengan tingginya intensitas aktivitas di Kota Pontianak tentunya akan semakin tinggi pula tingkat kerugian yang didapatkan apabila terjadi bencana kebakaran yang melanda kawasan tersebut yang hampir selalu terjadi di setiap tahunnya.

Pada penelitian ini di fokuskan di Kota Pontianak, karena Kota Pontianak memiliki potensi terhadap bencana kebakaran yang cukup besar, hal tersebut juga dipengaruhi oleh kepadatan bangunan yang tinggi dan peningkatan jumlah penduduk. Kebakaran yang terjadi di Kota Pontianak merupakan suatu fenomena yang selalu terjadi setiap tahunnya dan jumlah kejadian lima tahun terakhir juga menunjukan di Kota Pontianak jumlah kejadian termasuk yang paling besar dibandingkan dengan kota/kabupaten lainnya yang ada di Provinsi Kalimantan Barat yaitu dengan jumlah kejadian berkisar 40 sampai 60 kejadian kebakaran permukiman.

Tabel 2. Kejadian Kebakaran per Kecamatan di Kota Pontianak Tahun 2015 (BPBD Kota Pontianak, 2015)

\begin{tabular}{|l|c|}
\hline \multicolumn{1}{|c|}{ Kecamatan } & $\begin{array}{c}\text { Kejadian } \\
\text { Kebakaran }\end{array}$ \\
\hline Pontianak Kota & 14 \\
\hline Pontianak Utara & 13 \\
\hline Pontianak Barat & 10 \\
\hline Pontianak Selatan & 13 \\
\hline Pontianak Timur & 3 \\
\hline Pontianak Tenggara & 2 \\
\hline Kota Pontianak & $\mathbf{5 5}$ \\
\hline
\end{tabular}

Pemicu terjadinya kebakaran di kawasan permukiman perkotaan itu sendiri adalah kurangnya ketangguhan dalam menahan bencana itu sendiri. Ketangguhan disini mengacu kepada pengurangan kerentanan yang menjadi potensi bahaya kebakaran di kawasan permukiman. Pada penelitian ini akan menganalisis tingkat ketangguhan terhadap kebakaran di Kota Pontianak, identifikasi ketangguhannya pun dilakukan dengan melihat bagaimana kondisi fisik, sosial, ekonomi, dan institusi. Ketangguhan aspek ekonomi yang dibahas pada penelitian ini yaitu dengan melihat ketangguhan masyarat setelah terjadi bencana kebakaran, atau melihat kemampuan masyarakat dari sisi ekonomi apakah memiliki investasi untuk membangun kembali rumah yang telah terbakar pasca bencana kebakaran.

\section{TINJAUAN PUSTAKA}

The United Nations Office for Disaster Risk Reduction (UNISDR, 2012) mengartikan ketangguhan sebagai kemampuan untuk bertahan terhadap, menyerap, berakomodasi, dan pulih dari dampak bencana dengan tepat pada waktunya dan secara efisien. Djalante dalam Akhmad (2015) mendifinisikan ketangguhan sebagai kemampuan dari masyarakat untuk menahan, menyerap, mengakomodir, dan pulih dari bahaya secara singkat dan efisien. Timmerman dalam Meirizky (2015) menjelaskan bahwa ketangguhan merupakan suatu tindakan dari sistem atau bagian dari kapasitas sistem dalam menyangga dan memulihkan dari suatu peristiwa berbahaya.

Tabel 3. Kejadian Kebakaran per Kecamatan di Kota Pontianak Tahun 2015 (CARRI, 2008) 


\begin{tabular}{|l|l|}
\hline \multicolumn{1}{|c|}{ Definisi Ketangguhan } & \multicolumn{1}{|c|}{ Sumber } \\
\hline $\begin{array}{l}\text { Kapasitas sistem, komunitas, atau masyarakat yang berpotensi terkena bahaya } \\
\text { untuk beradaptasi, dengan menolak atau mengubah untuk mencapai dan }\end{array}$ & $\begin{array}{l}\text { Subcommittee } \\
\text { Reduction (SDR), } 2005\end{array}$ \\
mempertahankan struktur. Hal ini ditentukan oleh sejauh mana sistem sosial \\
yang mampu mengorganisir diri untuk meningkatkan kapasitas dengan belajar \\
dari bencana masa lalu untuk perlindungan masa depan yang lebih baik dan \\
untuk meningkatkan langkah-langkah pengurangan risiko.
\end{tabular}

\section{DATA DAN METODOLOGI}

\subsection{Data Lokasi Penelitian}

Unit amatan dalam melihat ketangguhan kota dalam aspek ekonomi yaitu pada 6 Kecamatan yang ada di Kota Pontianak. Pada gambar 1 menunjukkan Enam kecamatan di Kota Pontianak ,antara lain Kecamatan Pontianak Utara, Kecamatan Pontianak Kota, Kecamatan Pontianak Timur, Kecamatan Pontianak Barat, Kecamatan Pontianak Selatan, dan Kecamatan Pontianak Tenggara. Salah satu kota yang memiliki karakteristik dan potensi bencana kebakaran seperti yang telah dijelaskan di atas adalah Kota Pontianak. Kota Pontianak memiliki kawasan perkotaan yang cukup padat, baik dari segi penduduk maupun bangunan.

Kota Pontianak merupakan Ibukota Provinsi Kalimantan Barat dengan luas mencakup 107,82 $\mathrm{Km}^{2}$ yang terdiri dari 6 Kecamatan dan 29 kelurahan. Kota Pontianak dilintasi oleh garis Khatulistiwa yaitu pada $0^{\circ} 02^{\prime}$ 24" Lintang Utara sampai dengan $0^{\circ} 05^{\prime} 37^{\prime \prime}$ Lintang Selatan dan $109^{\circ} 16^{\prime} 25^{\prime \prime}$ Bujur Timur sampai dengan $109^{\circ} 23^{\prime} 01^{\prime \prime}$ Bujur Timur. Ketinggian Kota Pontianak berkisar antara 0,10 meter sampai 1,50 meter diatas permukaan laut.

Adapun kecamatan di Kota Pontianak yang mempunyai wilayah terluas adalah Kecamatan Pontianak Utara (34,52 persen), diikuti oleh Kecamatan Pontianak Barat (15,25 persen), Kecamatan Pontianak Kota (14,39 persen), Kecamatan Pontianak Tenggara $(13,75)$, Kecamatan Pontianak Selatan $(13,49)$ dan Kecamatan Pontianak Timur (8,14 persen). Di dalam wilayah Kota Pontianak banyak terdapat sungaisungai dan parit-parit yang keseluruhannya berjumlah 33 sungai/parit. Sungai/parit tersebut dimanfaatkan oleh sebagian masyarakat untuk keperluan sehari hari dan sebagai penunjang sarana transportasi. Jumlah penduduk Kota Pontianak mencapai 579.169 jiwa penduduk pada akhir tahun 2014 (BPS Kota Pontianak, 2015). 


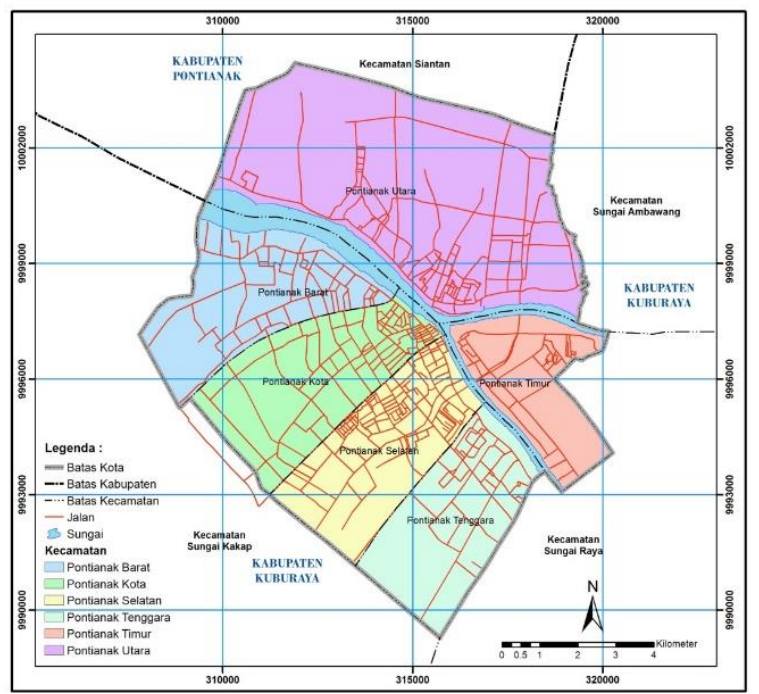

Gambar 1. Peta Administrasi Kota Pontianak (Bappeda Kota Pontianak, 2015)

\subsection{Metodologi}

Unit analisis dari penelitian ini adalah upaya-upaya yang telah dilakukan pemangku kepentingan (pemerintah, swasta, dan masyarakat) dalam mewujudkan ketangguhan kota. Dalam penentuan variabel digunakan konsensus pendapat para ahli mengenai ketangguhan terhadap bencana. Berdasarkan konsensus tersebut dapat teridentifikasi variabel ketangguhan ekonomi untuk mengukur ketangguhan kota Pontianak terhadap bencana kebakaran seperti terlihat pada table 3 berikut ini.

Tabel 4. Variabel Ketangguhan Ekonomi (Penulis, 2016)

\begin{tabular}{|c|c|c|c|c|}
\hline $\begin{array}{c}\text { Variabel } \\
\text { Operasional }\end{array}$ & Indikator & Standar & Jenis Data & Sumber \\
\hline $\begin{array}{l}\text { Tingkat } \\
\text { Kemiskinan }\end{array}$ & $\begin{array}{l}\text { Semakin rendah } \\
\text { tingkat kemiskinan } \\
\text { maka tingkat } \\
\text { ketangguhan } \\
\text { semakin tinggi }\end{array}$ & $\begin{array}{l}\text { Rumah tangga miskin biasanya tidak } \\
\text { memiliki tabungan atau investasi lain, } \\
\text { apabila rumah dan hartanya hangus } \\
\text { terbakar maka mereka ridak memiliki } \\
\text { apapun lagi. }\end{array}$ & Sekunder & $\begin{array}{l}\text { The World Bank } \\
\text { (2012), MCEER } \\
\text { (2008) }\end{array}$ \\
\hline $\begin{array}{l}\text { Mata } \\
\text { Pencaharian }\end{array}$ & $\begin{array}{l}\text { Pengangguran yang } \\
\text { tidak memiliki mata } \\
\text { pencaharian } \\
\text { mempengaruhi } \\
\text { tingkat ketangguhan }\end{array}$ & $\begin{array}{l}\text { Semakin rendah } \quad \text { tingkat } \\
\text { pengangguran maka tingkat } \\
\text { ketangguhannya semakin tinggi }\end{array}$ & Sekunder & $\begin{array}{l}\text { Climate Disaster } \\
\text { Resilience } \\
\text { Initiative (2009) }\end{array}$ \\
\hline
\end{tabular}

Teknik pengumpulan data dilakukan melalui pengumpulan informasi dan literatur, dan pencarian data kuantitatif (data sekunder) yang diperoleh dari instansi atau lembaga terkait permasalahan dalam penelitian ini yaitu bencana kebakaran. Sedangkan variabel ketangguhanan ekonomi menggunakan jenis data sekunder dari BPS (Badan Pusat Statistik).

Sedangkan metode analisis yang digunakan dalam penelitian ini menggunakan metode campuran (mixed methods), yaitu menggunakan analisis spasial dan analisis kualitatif. penelitian mengenai ketangguhan kota terhadap bencana kebakaran menggunakan pendekatan penelitian deduktif dan metode campuran (mixed-method). Metode campuran (mixed methods) adalah menggunakan dua metode atau lebih metode yang diambil dari dua pendekatan yang berbeda, yaitu pendekatan kuantitatif atau kualitatif (dapat sebaliknya) dalam riset yang sedang dijalankan (Sarwono, 2010).

Sedangkan menurut Cresswell dalam Rivany (2015) metode campuran adalah rancangan untuk mengumpulkan, menganalisis, dan mencampurkan data baik kuantitatif dan kualitatif dalam satu atau 
serangkaian penelitian untuk memahami masalah dalam penelitian evaluasi. Menurut Brymann dalam Rivany (2015) alasan-alasan seperti diatas merupakan alasan yang dapat dijadikan dasar untuk menggunakan metode campuran dalam mengukur upaya ketangguhan.

Adapun data-data yang telah dikumpulkan selanjutnya dilakukan analisis untuk mengetahui tingkat ketangguhan Kota Pontianak dari aspek ekonomi seperti terlihat pada tabel 4. Skoring ketangguhan menggunakan metode klasifikasi aritmatik. Seperti penelitian mengenai ketangguhan sebelumnya yang telah dilakukan Meirizky (2015) dan Sari (2014), mereka menilai ketangguhan dengan menggunakan metode klasifikasi aritmatik.

Tabel 5. Skoring Penilaian Variabel Ketangguhan Ekonomi Terhadap Kebakaran (Penulis, 2016)

\begin{tabular}{|c|c|c|}
\hline $\begin{array}{c}\text { Variabel } \\
\text { Konsepsual }\end{array}$ & $\begin{array}{c}\text { Variabel } \\
\text { Operasional }\end{array}$ & Skor Ketangguhan \\
\hline \multirow{2}{*}{$\begin{array}{c}\text { Ketangguhan } \\
\text { Ekonomi }\end{array}$} & $\begin{array}{l}\text { Tingkat } \\
\text { Kemiskinan }\end{array}$ & \multirow{2}{*}{$\begin{array}{l}1=\text { Sangat Tinggi } \\
2=\text { Tinggi } \\
3=\text { Sedang } \\
4=\text { Rendah } \\
5=\text { Sangat Rendah }\end{array}$} \\
\hline & Mata Pencaharian & \\
\hline
\end{tabular}

Penggunaan metode tersebut dikarena ketangguhan merupakan ilmu baru dan multisektor dan belum terdapat indeks ataupun standar ketangguhan maka dari itu pengukurannya akan lebih baik apabila menggunakan metode klasifikasi aritmatik (Sari, 2014). Adapun klasifikasi aritmatik yang digunakan untuk mengkelaskan data kuantitatif yaitu dengan rentang nilai. Rentang maksimum dan minimum dari data kuantitatif dibagi menjadi 5 untuk memperoleh interval kelas (Meirizky, 2015). Misalnya, rentang $0-100$ memiliki interval kelas 20 yaitu $0-20$ sangat rendah, $21-40$ rendah, $41-60$ sedang, $61-80$ tinggi, dan 81 -100 sangat tinggi.

Gambar 2 menunjukkan kerangka piker lebih lanjut dalam penelitian selanjutnya dilakukan analisis spasial untuk mengetahui tingkat ketangguhan dan dilanjutkan dengan analisis jaringan untuk mengidentifikasi jangkauan pelayanan pemadam kebakaran ke daerah - daerah yang masih belum tangguh terhadap bencana kebakaran. Output dari analisis spasial dan analisis jaringan selanjutnya akan di overlay, setelah itu di dapatkanlah daerah yang tingkat ketangguhannya sangat tinggi, tinggi, sedang, rendah, dan sangat rendah.

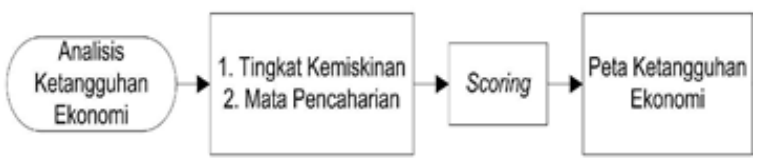

Gambar 2. Kerangka Pikir (Penulis, 2016)

\section{HASIL DAN PEMBAHASAN}

Ketangguhan ekonomi menggambarkan tangguhnya masyarakat dalam menghadapi besarnya kerugian yang dialami pasca kejadian kebakaran. Terdapatnya rumah tangga miskin karena disebabkan oleh tingkat perekonomian pada suatu keluarga tersebut rendah. Adanya rumah tangga miskin mempengaruhi tingkat ketangguhan di Kota Pontianak. Rata-rata pekerjaan penduduk miskin di Kota Pontianak pekerjaannya adalah pemulung dan pengemis. Penduduk miskin di Kota Pontianak biasanya menempati rumah dengan jenis bangunan kayu dan apabila setelah terjadi kebakaran penduduk miskin tidak punya investasi untuk membangun rumahnya kembali. Dari hal tersebutlah dapat terlihat tingkat ketangguhan penduduk miskin terhadap bahaya kebakaran di Kota Pontianak. Dari data sekunder tentang jumlah rumah tangga miskin di 
Kota Pontianak didapatkanlah jumlah rumah tangga miskin di masing-masing Kecamatan seperti terlihat pada gambar 3 dan tabel 5 berikut ini.

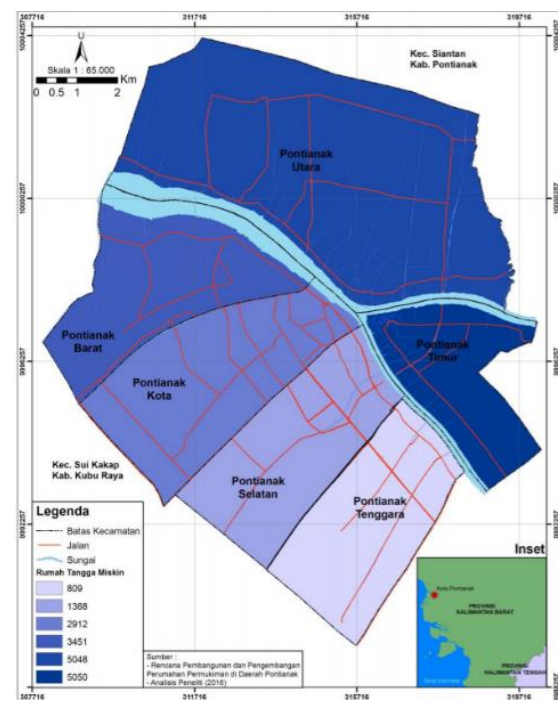

Gambar 3. Peta Rumah Tangga Miskin di Kota Pontianak (Penulis, 2016)

Dari peta rumah tangga miskin tersebut, didapat pembagian jumlah rumah tangga miskin yang ada di Kota Pontianak. Diantara semua kecamatan yang ada di Kota Pontianak, Kecamatan Pontianak Timur memiliki persentase rumah tangga miskin paling besar diantara kecamatan yang ada di Kota Pontianak yaitu $25 \%$, sedangkan persentase paling kecil terdapat di Kecamatan Pontianak Selatan yaitu hanya 6\%. Peta skor rumah tangga miskin didapat disesuaikan dengan tabel skor rumah tangga miskin yang disesuaikan dengan tingkat ketangguhan terhadap kebakaran.

Tabel 6. Jumlah Rumah Tangga Miskin (Penulis, 2016)

\begin{tabular}{|c|c|c|c|}
\hline Blok Kecamatan & $\begin{array}{c}\text { Jumlah Rumah } \\
\text { Tangga }\end{array}$ & $\begin{array}{c}\text { Skor } \\
\text { Ketangguhan }\end{array}$ & $\begin{array}{c}\text { Persentase } \\
\text { RTM (\%) }\end{array}$ \\
\hline Pontianak Kota & 27221 & 2912 & 11 \\
\hline Pontianak Utara & 288970 & 5048 & 18 \\
\hline Pontianak Barat & 12346 & 3451 & 10 \\
\hline Pontianak Selatan & 22610 & 1368 & 6 \\
\hline Pontianak Tenggara & 10486 & 809 & 8 \\
\hline Pontianak Timur & 16151 & 5050 & 25 \\
\hline
\end{tabular}

Tabel 6 dan gambar 4 dibawah ini menjelaskan bahwa rumah tangga miskin terdapat 2 kecamatan yang menduduki skor 1 atau tingkat ketangguhan "sangat tinggi" yaitu pada kecamatan Pontianak Selatan dan Kecamatan Pontianak Tenggara. Untuk skor 2 atau tingkat ketangguhan yang "tinggi" juga diduduki oleh 2 kecamatan yaitu kecamatan Pontianak Kota dan kecamatan Pontianak Barat. Sedangkan skor 4 dan 5 masing masing hanya diduduki oleh satu kecamatan. Dari penjelasan tersebut, dapat diidentifikasi bahwa kawasan tangguh kebakaran dari sisi ekonomi cukup banyak di Kota Pontianak, yaitu terdapat 4 kecamatan dari 6 kecamatan yang ada di Kota Pontianak. 
Tabel 7. Skor Rumah Tangga Miskin (Penulis, 2016)

\begin{tabular}{|c|c|c|}
\hline Kriteria & Skor & Tingkat Ketangguhan \\
\hline$<9,8 \%$ jumlah Rumah Tangga Miskin & 1 & Sangat Tinggi \\
\hline $9,8 \%-13,5 \%$ jumlah Rumah Tangga Miskin & 2 & Tinggi \\
\hline $13,6 \%-17,3 \%$ jumlah Rumah Tangga Miskin & 3 & Sedang \\
\hline $17,4 \%-21,2 \%$ jumlah Rumah Tangga Miskin & 4 & Rendah \\
\hline$>21,2 \%$ jumlah Rumah Tangga Miskin & 5 & Sangat Rendah \\
\hline
\end{tabular}

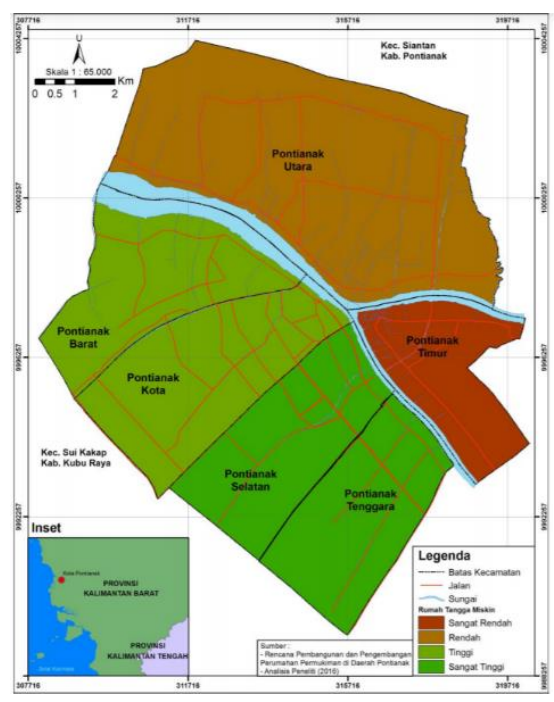

Gambar 4. Peta Ketangguhan Rumah Tangga Miskin di Kota Pontianak (Penulis, 2016)

Walaupun demikian, dilihat dari segi luas wilayahnya seperti terlihat pada tabel 7 dibawah, yang paling mendominasi adalah skor 4 atau tingkat ketangguhan "rendah" walaupun skor 4 hanya diduduki satu kecamatan, yaitu Kecamatan Pontianak Timur. Luas lahan skor 4 adalah 3899 ha atau 36,3\%, sedangkan skor 1 dan skor 2 yang diduduki masing-masing 2 kecamatan hanya memiliki luas lahan 2852 ha atau 26,6\% (skor 1) dan 2990 ha atau 27,9\% (skor 2). Dan yang paling kecil luas lahannya adalah skor 5 atau dengan tingkat ketangguhan sangat rendah yaitu pada Kecamatan Pontianak Timur dengan luas lahan 992 ha atau 9,2\%. Dari penjelasan tersebut dapat diketahui bahwa Kota Pontianak didominasi oleh skor 4 atau tingkat ketangguhan yang "rendah".

Tabel 8. Hasil Skor Rumah Tangga Miskin (Penulis, 2016)

\begin{tabular}{|c|l|c|}
\hline Skor & \multicolumn{1}{|c|}{ Blok } & Luas (Ha) \\
\hline 1 & $\begin{array}{l}\text { Kecamatan Pontianak Selatan dan Kecamatan } \\
\text { Pontianak Tenggara }\end{array}$ & 2852 \\
\hline 2 & $\begin{array}{l}\text { Kecamatan Pontianak Kota dan Kecamatan } \\
\text { Pontianak Barat }\end{array}$ & 2990 \\
\hline 3 & - & - \\
\hline 4 & Kecamatan Pontianak Utara & 3899 \\
\hline 5 & Kecamatan Pontianak Timur & 1092 \\
\hline
\end{tabular}




\section{KESIMPULAN}

Kebakaran yang terjadi di Kota Pontianak lebih tinggi dibandingkan kota/kabupaten lainnya di Kalimantan Barat. Penelitian ketangguhan ekonomi menggambarkan tangguhnya masyarakat dalam menghadapi besarnya kerugian yang dialami pasca kejadian kebakaran. Persentase rumah tangga miskin paling besar diantara kecamatan yang ada di Kota Pontianak yaitu $25 \%$, sedangkan persentase paling kecil terdapat di Kecamatan Pontianak Selatan yaitu hanya 6\%. Ditinjau dari rumah tangga miskin, terdapat 2 kecamatan yang menduduki skor 1 atau tingkat ketangguhan "sangat tinggi" yaitu Kecamatan Pontianak Selatan dan Kecamatan Pontianak Tenggara. Sedangkan dilihat dari segi luas wilayahnya bahwa yang paling mendominasi adalah skor 4 atau tingkat ketangguhan "rendah" yaitu Kecamatan Pontianak Timur. Secara keseluruhan bahwa Kota Pontianak didominasi oleh skor 4 atau tingkat ketangguhan yang "rendah".

\section{DAFTAR PUSTAKA}

Badan Pusat Statistik. Kota Pontianak Dalam Angka 2015. Pontianak.

Community and Regional Resilience Initiative (CARRI). (2008). Community and Regional Resilience: Perspective From Hazards, Disasters, and Emergency Management. CARRI Research Report 1.

Mantra, Ida Bagus Gede Wirawibawa. 2005. Kajian Penanggulangan Bahaya Kebakaran Pada Perumahan (Suatu Kajian Pendahuluan di Perumahan Sarijadi Bandung). Jurnal Permukiman Natah Vo. 3 No. 1. Universitas Udayana. Bandung.

Meirizky, Hanifah Carissa. (2015). Sebaran Tingkat Ketahanan Masyarakat Permukiman Padat Tepi Sungai Musi Terhadap Bencana Kebakaran Kelurahan 5 Ulu, Kecamatan Seberang Ulu I, Kota Palembang. Yogyakarta: Tugas Akhir PWK UGM.

Rivany, Mochamad Azhar. (2015). Evaluasi Efektivitas Implementasi Program Rehabilitasi dan Rekonstruksi Permukiman Berbasis Komunitas (REKOMPAK) Pascabencana Erupsi Gunung Merapi di Kabupaten Sleman 2011-2014. Yogyakarta: Tesis MPKD UGM.

Sagala, Saut. (2014). Perilaku dan Kesiapsiagaan Terkait Kebakaran Pada Penghuni Permukiman Padat Kota Bandung. Sekolah Arsitektur dan Perencanaan, ITB, Bandung.

Sari, Bulan Nirwana. (2014). "Sebaran Tingkat Ketahanan Masyarakat Terhadap Bencana Banjir Lahar Hujan Sungai Code". Yogyakarta: Tugas Akhir PWK UGM.

Sarwono, Jonathan. (2010). Mixed Methods: Cara Menggabungkan Riset Kuantitatif dan Riset Kualitatif Secara Benar. PT Elex Media Komputindo. Kompas Gramedia. 